\title{
Monitoring Perkembangan Anak Usia Balita Berbasis Aplikasi Mobile Android
}

\author{
Nur Laili Febriyanti ${ }^{1 *}$, Maulidiansyah ${ }^{1}$, Zainal Arifin $^{1}$ \\ ${ }^{1}$ Universitas Nurul Jadid \\ Jl. PP Nurul Jadid Karanganyar Paiton Probolinggo 67291 Jawa Timur \\ * nurlailifebriyanti22@gmail.com \\ DOI: https://doi.org/10.21107/rekayasa.v14i3.11385
}

\begin{abstract}
Posyandu is a health activity organized by the community for the community, almost all villages have posyandu activities, including the village of Gungqun Lor. Posyandu in Gungqugan Lor in conveying schedule information, child development, and health information using the MCH book or orally when attending the Posyandu, the consultation process from the midwife is also face-to-face, the process has problems when the MCH book is lost and when the midwife or cadre forgets to convey the information needed, therefore an application is needed as an intermediary to convey the information, namely using a mobile (android) based application, with a modern development method, namely RAD (Rapid Application Development) toddler mother
\end{abstract}

Key words : android, toddler, health, monitoring

\section{PENDAHULUAN}

Kesehatan dasar yang diselenggarakan dari, dan untuk masyarakat dan di bantu oleh petugas kesehatan desa ataupun petugas kesehatan kecamatan dan daerah setempat (Kesehatan, 2011). Posyandu berperan penting bagi perkembangan Kesehatan masyarakat desa pada tiap-tiap wilayah atau RT/RW dalam suatu desa, posyandu pada umumnya hanya melayani balita, ibu hamil, dan orang lanjut usia (lansia). Pada kegiatan Posyandu khusunya pada ibu hamil dan anak dilakukan dengan menggunakan buku KIA. Buku KIA sendiri merupakan buku kesehatan perkembangan ibu hamil dan anak, dalam edisi keluaran terbaru buku KIA kini dibagi menjadi dua bagian, yaitu buku untuk pencatatan perkembangan anak dan buku untuk pencatatan ibu hamil. Setiap desa pasti mempunyai gerakan kegiatan yang dinamakan posyandu, tidak terkecuali pada Desa Gunggungan Lor.

Kegiatan posyandu yang ada di Desa Gunggungan Lor merupakan salah satu kegiatan puskesmas Kecamatan Pakuniran. Menurut

\section{Article History:}

Received: June, 30 ${ }^{\text {th }}$ 2021; Accepted: November, $17^{\text {th }} 2021$

Rekayasa ISSN: 2502-5325 has been Accredited by Ristekdikt (Arjuna) Decree: No. 23/E/KPT/2019 August 8th, 2019 effective until 2023 petugas di Desa Gunggungan kegiatan posyandu dilakukan dalam tiga kali dalam satu bulan. Pelaksanaan kegiatan posyandu dibantu oleh lima kader dengan setiap kader memiliki tugas masingmasing diantaranya : (1) Mencatat daftar hadir posyandu; (2) Melakukan pengukuran dan penimbangan balita; (3) Mencatat hasil pengukuran dan penimbangan di buku KIA; (4) Memberikan penyuluhan terkait perkembangan anak sesuai umur masing-masing bayi dan balita

Penelitian yang dilakukan oleh Fitriana (2019) menyatakan bahwa sistem pencatatan tersebut memiliki efek negatif, yaitu jika buku KIA hilang atau lupa dibawa maka proses pemantauan pertumbuhan balita akan terganggu, selain itu data-data yang dimiliki pihak posyandu dan pihak puskesmas tidak sinkron. Untuk mengatasi masalah tersebut maka dilakukan penelitian ini untuk merancang aplikasi yang dapat membantu pihak posyandu dan pihak puskesmas dalam pencatatan dan penyimpanan data yang dibutuhkan dalam pemantauan tumbuh kembang balita. Metode yang digunakan dalam penelitian

\section{Cite this as:}

Febriyanti, N.L., Maulidiyansyah \& Arifin, Z. (2021). Monitoring Perkembangan Anak Usia Balita Berbasis Aplikasi Mobile Android. Rekayasa 14 (3). 381-388. doi: https://doi.org/10.21107/rekayasa.v14i3.11385. 
ini yaitu metode Forward Chaining sehingga dapat disimpulkan dari hasil perhitungan apakah balita tersebut sehat atau tidak. penelitian ini menggunakan metode Rapid application development (RAD) sedangkan penelitian tersebut menggunakan metode Forward Chaining. Penelitian juga dilakukan oleh Sanitasari, dan Andreswari (2017) menyatakan bahwa perkembangan teknologi dapat dimanfaatkan untuk meningkatkan efisiensi dan efektivitas dalam dunia kesehatan dengan menggunakan sistem pakar. Penelitian lain dilakukan oleh Perwitasari dan Hendrawan (2020) untuk merancang dan membangun sistem monitoring perkembangan bayi untuk memantau pertumbuhan dan perkembangan bayi dan memberi kemudahan mengenai informasi dan pelayanan posyandu. Penelitian tersebut menghasilkan sistem penjadwalan dan monitoring perkembangan bayi berbasis android dengan menggunakan bahasa pemrograman Java android yang dapat mempermudah monitoring pertumbuhan dan perkembangan bayi dan penyajian informasi posyandu.

Penelitian yang sejenis juga dilakukan oleh Gumiri et al (2015) dengan menerapkan metode Naïve Bayes Classifier yang merupakan metode di dalam data mining untuk mengklasifikasikan data dengan memanfaatkan nilai probabilitas dari data dokumen contoh sebelumnya. Data yang menjadi acuan dalam penelitian tersebut adalah data perkembangan anak pada Posyandu, Sistem ini menentukan klasifikasi status perkembangan anak usia dini berdasarkan tiga kelas yaitu normal, suspect dan abnormal. Sistem dirancang menggunakan bahasa pemrograman Java. Penelitian lain juga dilakukan oleh Wiyono (2020) membahas salah satu pemanfaatan aplikasi smartphone berbasis android sebagai penunjang kegiatan operasional Posyandu (Pos Pelayanan Terpadu). Aplikasi kesehatan ibu dan anak dalam perancangannya menggunakan metode pengembangan UML (Unified Modeling Language) yang terdiri dari use case diagram, activity diagram, sequence diagram dan class diagram. Perancangan database menggunakan MySQL. Adapun software yang di gunakan dalam perancangan dan pengimplementasi sistem menggunakan XAMPP sebagai webserver, PhpMySQL sebagai database, Sublime text sebagai editor pengkodean program, Android Studio sebagai media membuat aplikasi android. Aplikasi Kesehatan Ibu dan Anak meliputi informasi kesehatan ibu dan anak, jadwal posyandu, catatan kesehatan ibu dan anak, kms, data pengguna, konsultasi, Sistem informasi telah di ujicoba menggunakan pengujian blackbox sehingga diperoleh sistem yang dapat membantu kader/bidan untuk bekerja secara lebih fleksibel.

Pada pelaksanaan kegiatan posyandu ada beberapa permasalahan yang sering terjadi salah satunya buku KIA hilang. Hal ini dapat mengakibatkan petugas kesulitan dalam memantau perkembangan anak dikarenakan petugas harus mencari catatan sebelumnya. Hilangnya buku KIA dapat memberikan dampak kesulitan kepada ibu-ibu dikarenakan salah satu fungsi dari buku KIA adalah untuk mengetahui perkembangan anaknya. Selain kesulitan dalam memonitoting perkembangan anak ialah sulitnya masyarakat dalam berkonsultasi karena harus menunggu kegiatan posyandu, tidak adanya pemberitahuan jadwal posyandu secara sistem smartphone membuat ibu balita yang sedang berada di luar lingkup desa tidak mengetahui informasi tersebut dan kurangnya pemahaman mengenai informasi kesehatan anak membuat masyarakat mudah menyepelekan hal tersebut sehingga terlambat melakukan penanganan.

Berdasarkan permasalahan di atas, maka diharapkan adanya suatu aplikasi untuk memonitoring perkembangan anak pada usia 0-5 tahun agar dapat mempermudah masyarakat dalam memonitoring perkembangan anaknya. Adapun beberapa fitur yang terdapat di dalam aplikasi monitoring perkembangan anak pada usia 0-5 tahun berbasis mobile Android seperti, terdapat histori perkembangan anak, informasi kegiatan posyandu, konsultasi dan berita kesehatan.

\section{METODE PENELITIAN}

Setelah identifikasi masalah dilakukan maka langkah selanjutnya adalah melakukan rencana kebutuhan dimana pada tahapan ini merupakan sebuah proses yang akan dilakukan pada penelitian ini dengan cara mengumpulkan datadata yaitu observasi, wawancara dan studi pustaka. Setelah kebutuhan terpenuhi selanjutnya melakukan proses perancangan sistem yang meliputi pembuatan Flowchart, DFD, ERD, dan pembuatan desain mockup aplikasi lalu diuji kepada pengguna apakah sesuai atau tidak, jika tidak sesuai maka dilakukan proses pengulangan desain dan jika sesuai maka dilanjutkan dengan 
proses membangun sistem, dimana proses pembangunan sistem dilakukan dengan cara pengkodean dan pengujian hasil kode apakah sesuai dengan keinginan pengguna atau tidak, proses tersebut dilakukan berulang sampai pengguna menyatakan sesuai, jika sudah sesuai maka dilakukan proses implementasi aplikasi tersebut di Posyandu Gunggungan Lor.

Metode pengembangan sistem menggunakan RAD (Rapid Aplication Development) merupakan model pengembangan perangkat lunak yang membutuhkan waktu pengerjaan yang yang singkat, cepat, dan bersifat incremental, metode pengembangan ini melibatkan user secara langsung dalam proses pengerjaannya. Dalam metode ini proses pengumpulan data juga berperan penting demi terciptanya sistem yang handal dengan system fungsional yang utuh, jika hal itu tercapai makan proses pengerjaan sebuah sistem menggunakan model ini berkisar antara 60 - 90 hari (Yurindra, 2017).

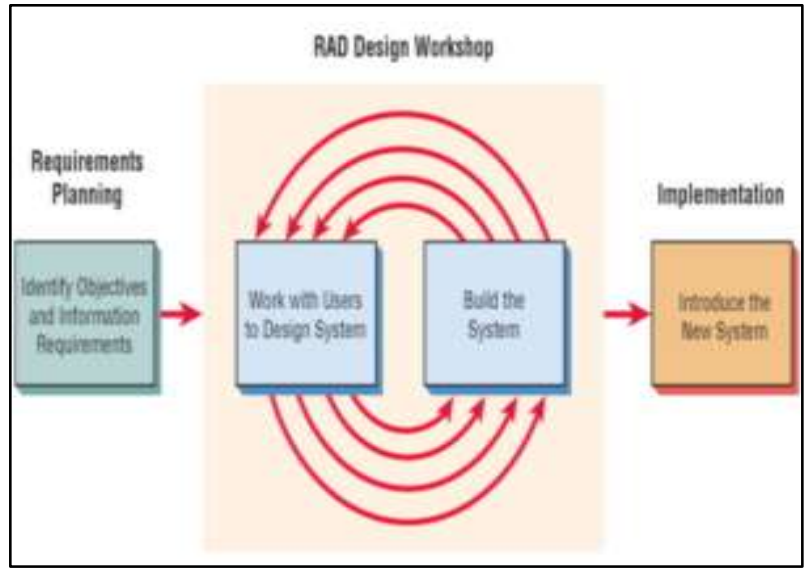

Gambar 1 Proses Pengembangan Model RAD

\section{Requirements Planning (Kebutuhan Perencanaan)}

Pada tahap ini perancang dan pengguna bertemu untuk melakukan perencanaa kebutuhan dengan menghasilkan data. Proses pendataan dilakukan dengan cara observasi tentang kegiatan posyandu, wawancara dengan pertanyaan kepada objek (bidan, kader dan ibu balita) serta studi pustaka sebagai acuan keilmuan tentang posyandu. Pada kegiatan ini dilakukan untuk mengumpulkan data-data yang berkaitan pengembangan sistem khususnya dalam proses memonitoring anak yaitu buku kesehatan ibu dan anak, hasil wawancara mengenai kesulitan dalam penyampaian informasi dan hasil observasi mengenai proses pelaksanaan dan teknis posyandu.

\section{Work with Users to Design System (Bekerja Dengan User untuk Membangun Sistem)}

Setelah semua data terkumpul dan dipelajari maka pengembang berinteraksi dengan pengguna untuk melakukan diskusi dan membangun desain sistem yang diinginkan, desain yang digunakan adalah normalisasi untuk mengurai data yang sudah ada, flowchart sebagai bagan alir sistem menggunakan aplikasi Edraw MinMap, DFD sebagai penentu aliran data menggunakan aplikasi Power Designer, ERD sebagai penentu hubungan antar entitas menggunakan aplikasi ThinkComposer, serta desain prototype sebagai gambaran sistem menggunakan mockup, hal ini dilakukan sampai pengguna menyatakan sudah benar.

\section{Build the System (Membangun Sistem)}

Setelah melakukan desain dengan pengguna maka selanjutnya membangun sistem sesuai dengan desain yang telah dibuat bersama pengguna, dari desain tersebut diterjemahkan kedalam sebuah aplikasi menggunakan bahasa pemrograman Java (Android) menggunakan aplikasi Android Studio, PHP dengan text editor notepad ++ atau Visual Studio Code, dan basis data penyimanan menggunakan MySQL, setelah proses penterjemahan tersebut maka hasil dari proses tersebut ditunjukkan kepada pengguna apakah sudah sesuai dengan sistem. Dalam proses ini setelah aplikasi diterjemahkan selanjutnya dilakukan uji coba terlebih dahulu.

\section{Introduce New System (Memperkenalkan Sistem Baru)}

Pada proses ini aplikasi sudah berhasil dibangun dan pengguna menyatakan sudah sesuai dengan alur sistem yang diinginkan, selanjutnya adalah proses pengenalan aplikasi kepada pengguna yang lain dengan model presentasi dan manual book sebagai buku pegangan pengguna. 


\section{HASIL DAN PEMBAHASAN}

Setelah melakukan proses pengumpulan data, langkah selanjutnya yaitu proses pengembangan system dimana pengembangan yang digunakan adalah RAD (Rapid Application Development) dengan urutan yaitu Perancanaan syarat-syarat, bekerja dengan pengguna, membangun system, dan pengenalan system, Adapun penjelasan lebih rincinya sebagai berikut:
1. Requirements
Planning
(Kebutuhan
Perencanaan)

Dari hasil observasi dan wawancara yang dilakukan di Posyandu Gunggungan Lor menghasilkan kesimpulan bahwa proses penyampaian informasi Kesehatan anak dilakukan satu-satunya menggunakan buku KIA dan rekapan buku pegangan kader dan bidan, sehingga kader dan ibu balita menyepakati beberapa hal yang harus dibenahi dengan adanya kecanggihan teknologi yaitu:

a. Proses penyampaian informasi (Jadwal posyandu, Informasi kesehatan) dilakukan dengan dibuatkan aplikasi monitoring informasi perkembangan anak.

b. Data yang disampaikan pada aplikasi adalah histori berat dan tinggi, histori pemberian imunisasi, histori pemberian vitamin, informasi Kesehatan, informasi jadwal, dan informasi bidan.

c. Ibu balita hanya diberikan akses terhadap aplikasi berbasis OS Android dengan spesifikasi (RAM 2 gb, memori min $1 \mathrm{gb}$, android min 7.0).

d. Proses konsultasi hanya menggunakan WhatsApp dengan menyematkan kontak bidan pada aplikasi.

e. Aplikasi dapat diakses setiap waktu menggunakan layanan server dari penyedia layanan.

f. Proses pencatatan pada buku KIA tetap ada.

2. Work with users to design system (Bekerja dengan user untuk membangun sistem)

Dalam proses ini menghasilkan beberapa rancangan dimana rancangan tersebut dikerjakan berdasarkan informasi dari pengguna dan konfirmasi dari pengguna apakah desain tersebut sudah sesuai dengan keinginan pengguna atau tidak, berikut hasil desain sistem berupa bagan alir sistem lama dan sistem baru.

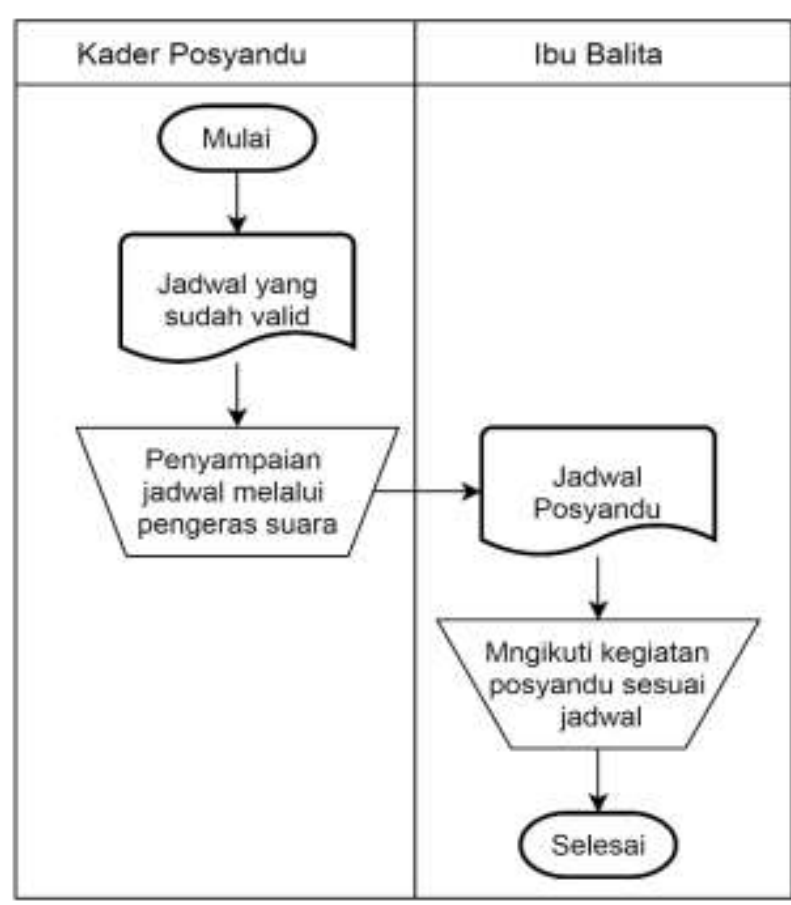

Gambar 2. Flowchart Sistem Lama Informasi Jadwal

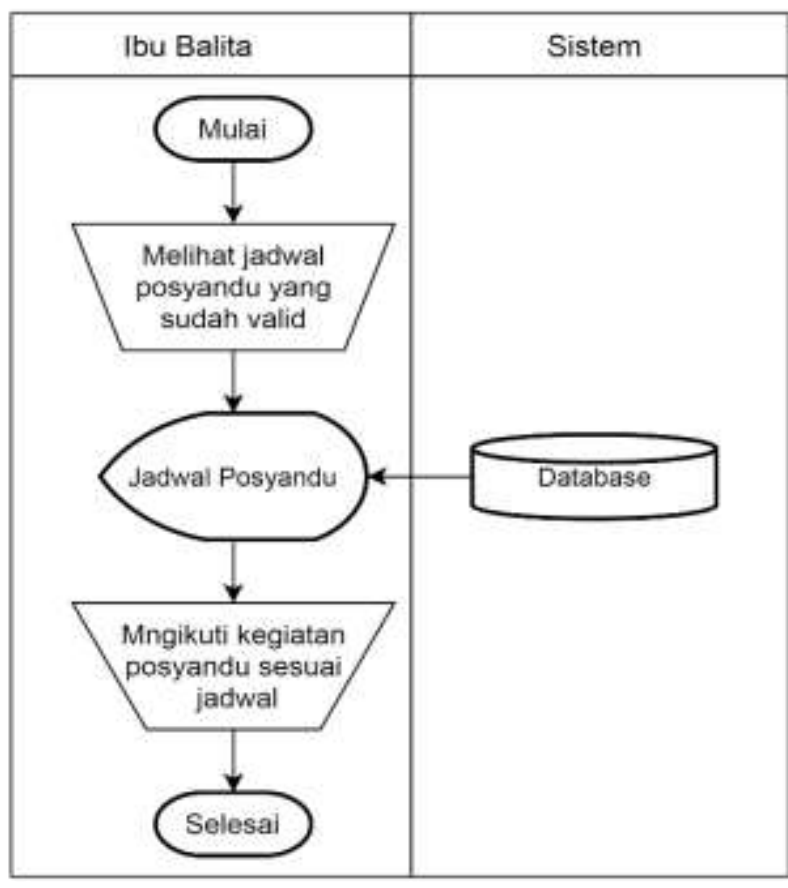

Gambar 3. Flowchart Sistem Baru Informasi Jadwal 


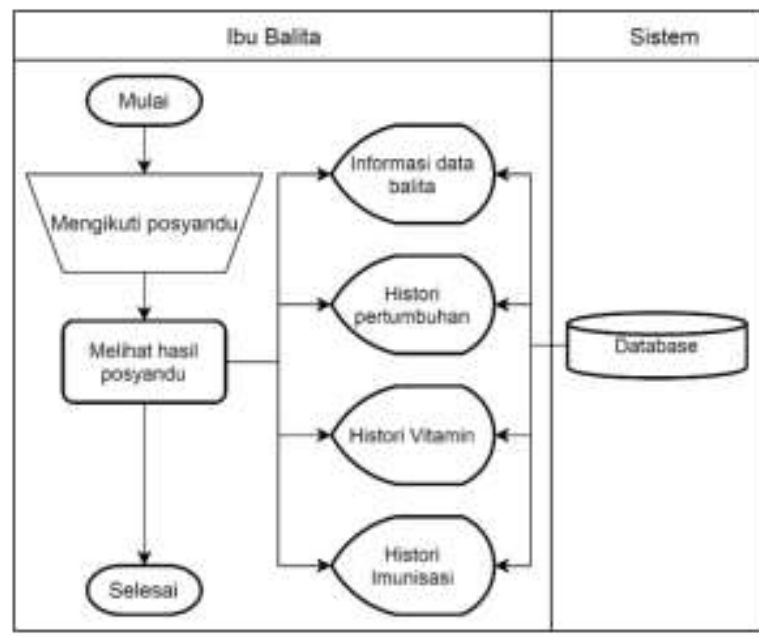

Gambar 4. Flowchart Sistem Baru Proses

Monitoring Posyandu

2. Build the system (Membangun sistem)

Dalam membangun sistem pengembang telah berkoordinasi dengan pengguna dan menghasilkan beberapa pengkodean. Proses pengkodean dilakukan menggunakan Bahasa pemrograman java berbasis android dan pemrograman PHP sebagai penghubung dengan penyimpanan data. Hasil dari pengkodean tersebut dihasilkan aplikasi yang bisa digunakan oleh pengguna.

Pada halaman login pengguna harus memasukkan NIK, jika benar maka pengguna diarahkan pada halaman beranda, dan jika salah makan muncul pesan salah (Gambar 5). Pada halaman beranda pengguna disuguhkan informasi data pengguna dan menu-menu yang bisa diakses (Gambar 6).

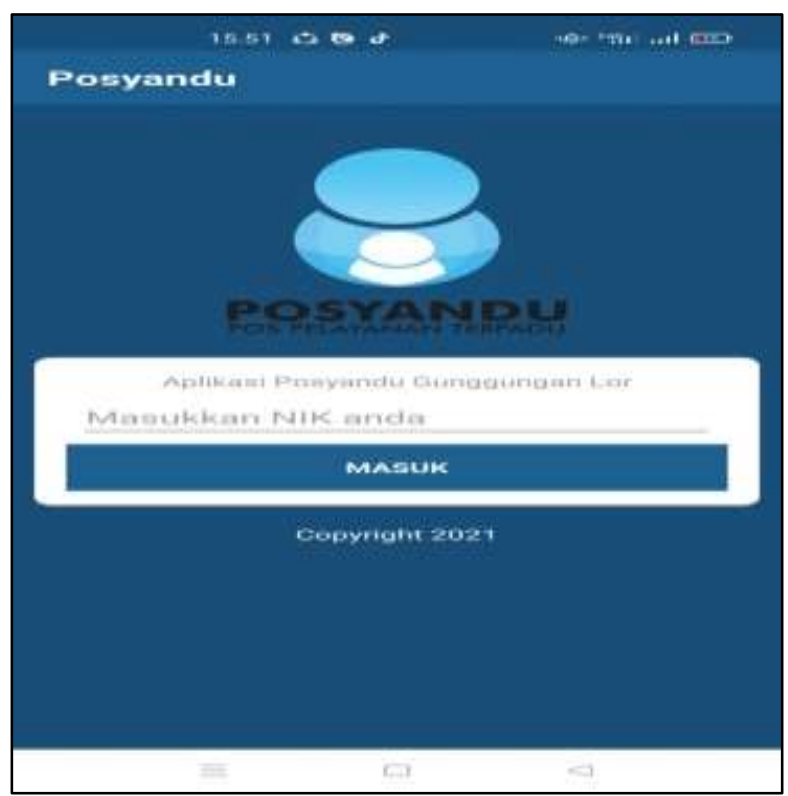

Gambar 5. Halaman Login

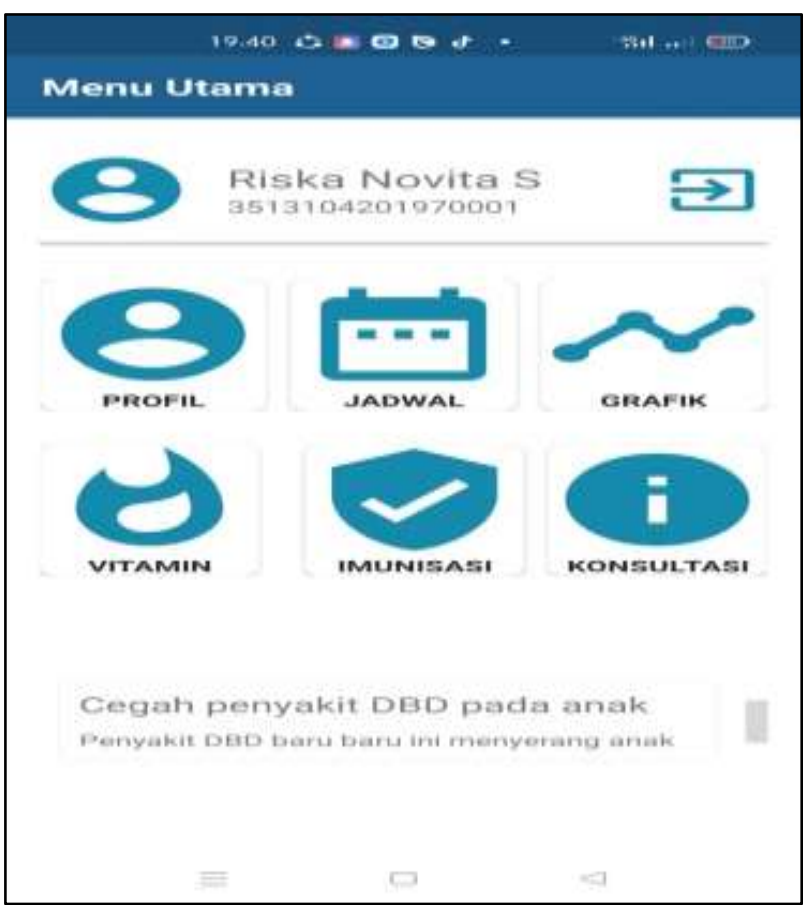

Gambar 6. Halaman Beranda Aplikasi

Pada halaman profil pengguna disuguhkan data profil pengguna dan informasi anak (Gambar 7). Selanjutnya pada halaman jadwal pengguna disuguhkan jadwal posyandu diurutkan dari jadwal terbaru dan jadwal yang sudah terlewat (Gambar 8). Sementara pada halaman pemberian imunisasi pengguna disuguhkan data histori pemberian imunisasi anak sesuai dengan anak yang terpilih (Gambar 9).

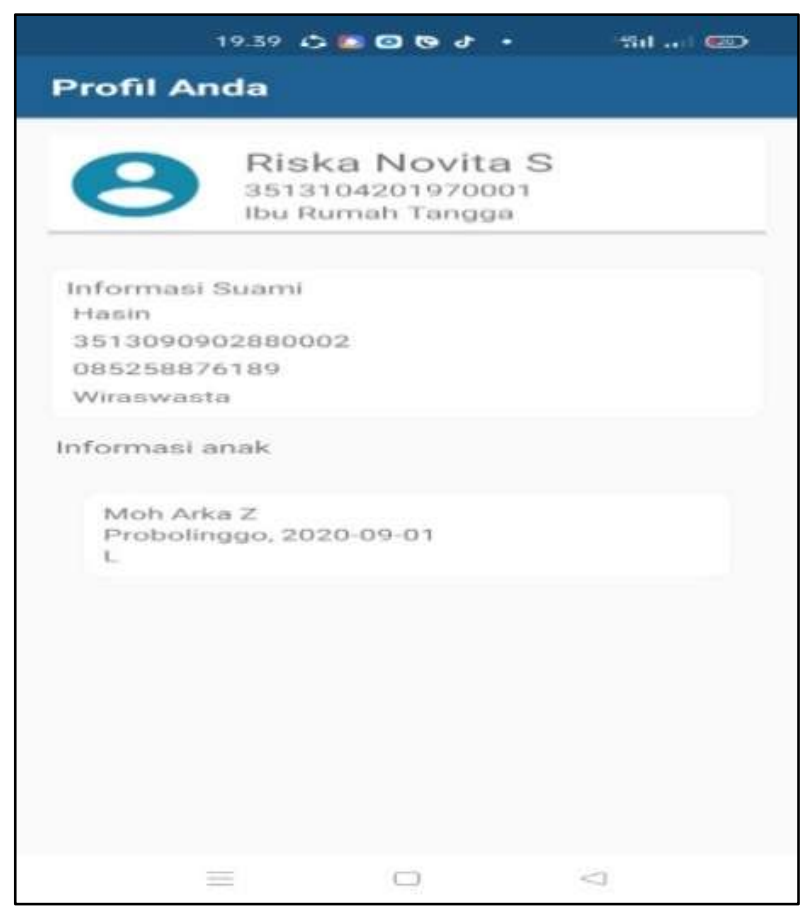

Gambar 7. Profil Pengguna 


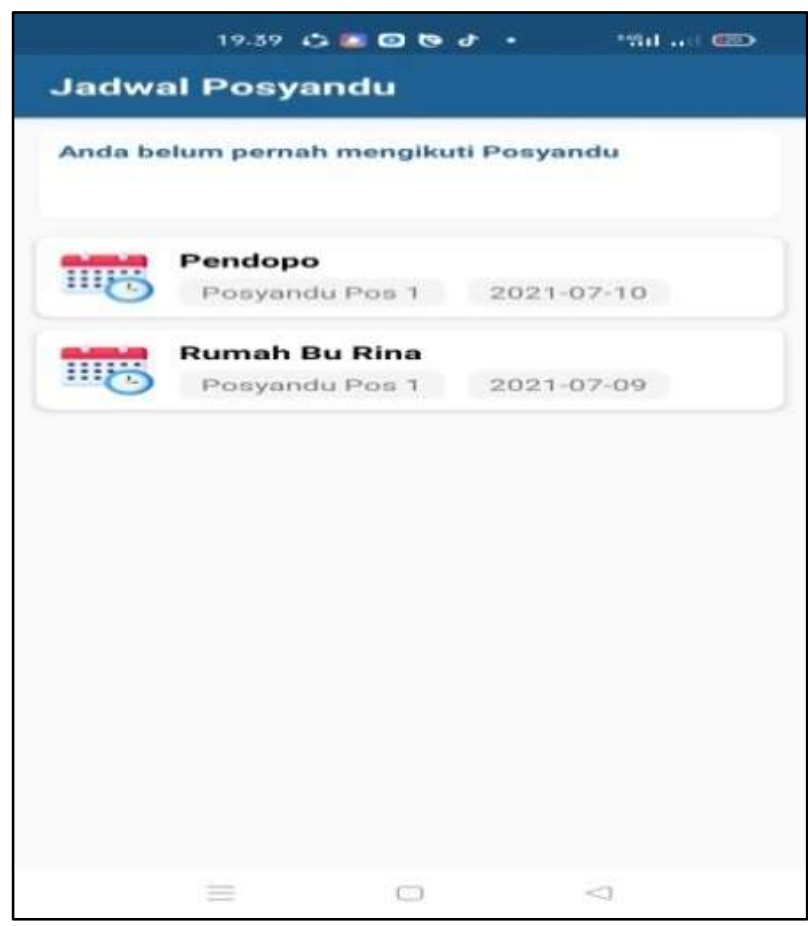

Gambar 8. Halaman Jadwal

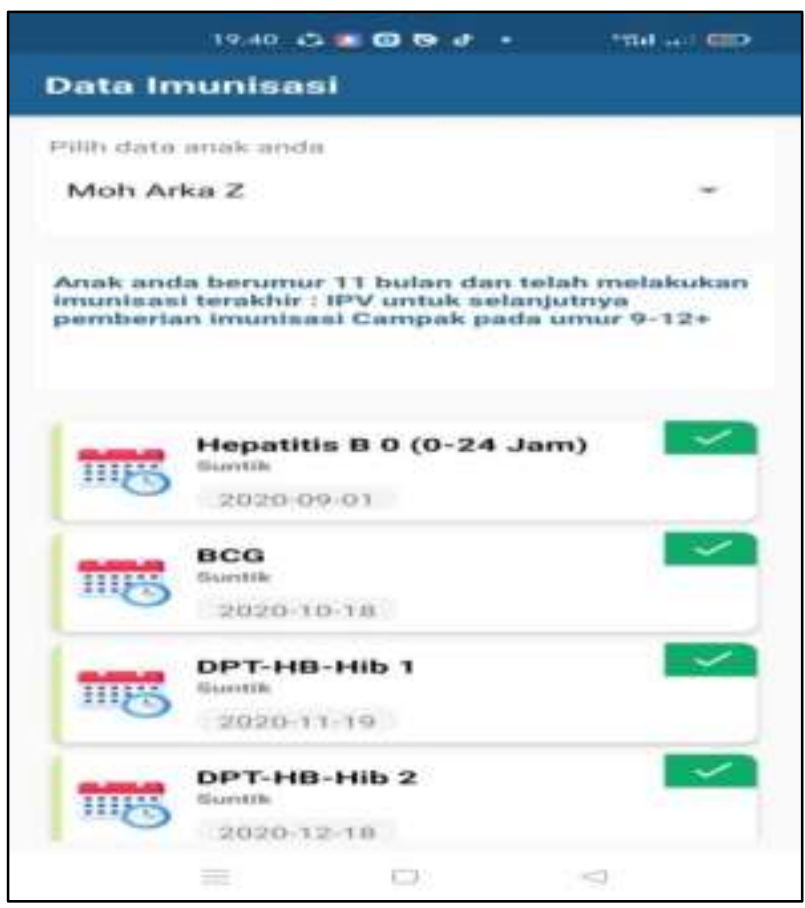

Gambar 9. Halaman Pemberian Imunisasi

Pada halaman pemberian vitamin pengguna disuguhkan histori pemberian vitamin sesuai dengan anak terpilih. Selanjutnya pada halaman grafik pengguna disuguhkan grafik perkembangan anak. Tampilan masing-masing halaman disajikan pada Gambar 10 dan 11 seperti dibawah ini.

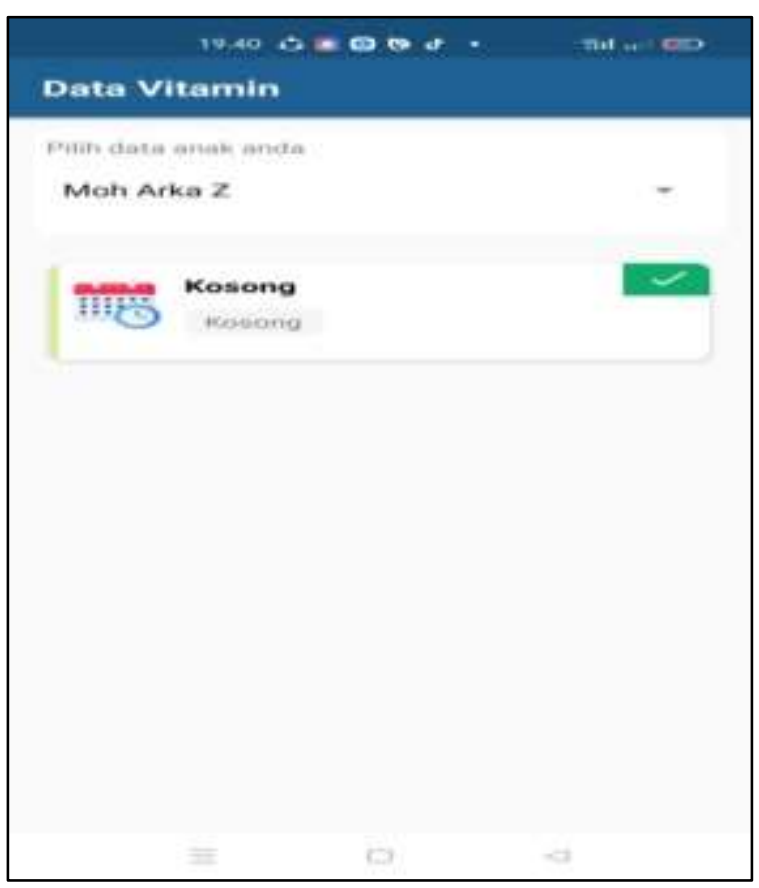

Gambar 10. Halaman Pemberian Vitamin

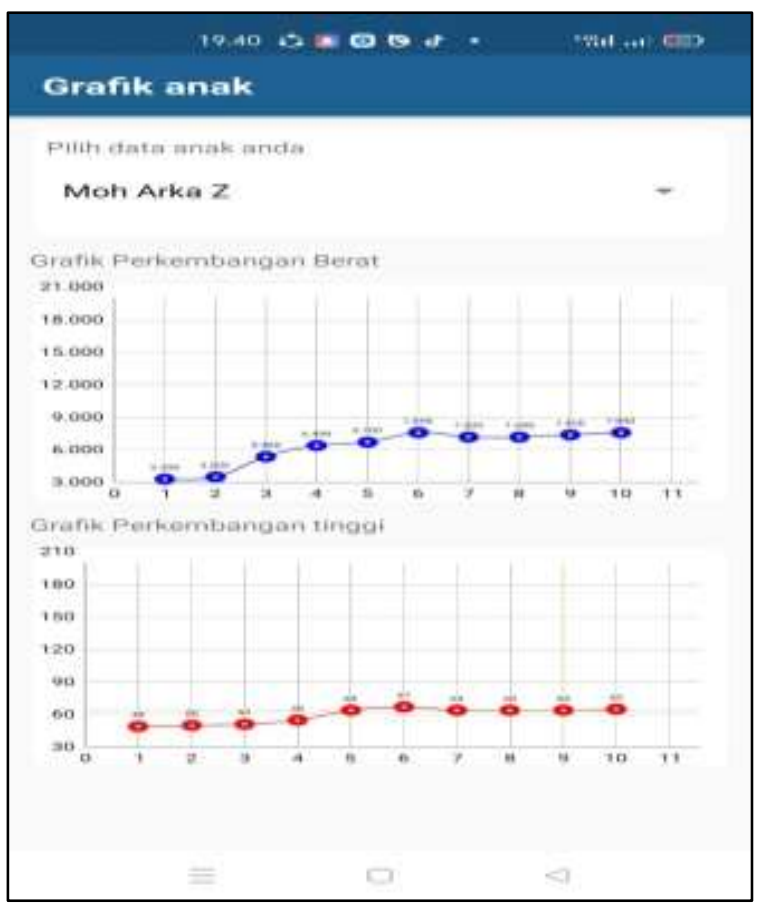

Gambar 11. Halaman Grafik Perkembangan Anak

Pengujian aplikasi yang dilakukan kepada pengguna langsung yaitu ibu balita. Hasil pengujian yang dilakukan ditunjukkan pada Tabel 1. 
Tabel 1. Hasil Pengujian Berdasar Persepsi Pengguna

\begin{tabular}{|c|c|c|c|c|c|c|}
\hline \multirow{2}{*}{ No. } & \multirow{2}{*}{ Pertanyaan } & \multicolumn{5}{|c|}{ Jawaban } \\
\hline & & SB & B & $C B$ & TB & STB \\
\hline 1 & $\begin{array}{l}\text { Apakah user atau } \\
\text { pengguna mengalami } \\
\text { kesulitan dalam } \\
\text { menjalankan sistem ini? }\end{array}$ & 0 & 10 & 0 & 0 & 0 \\
\hline 2 & $\begin{array}{l}\text { Apakah sistem telah } \\
\text { bekerja dengan baik? }\end{array}$ & 0 & 9 & 1 & 0 & 0 \\
\hline 3 & $\begin{array}{l}\text { Apakah semua fungsi } \\
\text { yang terdapat pada sistem } \\
\text { sudah sesuai dengan yang } \\
\text { diharapkan? }\end{array}$ & 0 & 10 & 0 & 0 & 0 \\
\hline 4 & $\begin{array}{l}\text { Apakah sistem yang baru } \\
\text { ini dapat membantu dan } \\
\text { memudahkan user dalam } \\
\text { memonitoring data } \\
\text { perkembangan anak? }\end{array}$ & 0 & 10 & 0 & 0 & 0 \\
\hline 5 & $\begin{array}{l}\text { Apakah sistem ini sudah } \\
\text { layak untuk digunakan } \\
\text { oleh ibu balita? }\end{array}$ & 0 & 10 & 0 & 0 & 0 \\
\hline 6 & $\begin{array}{l}\text { Apakah fitur yang } \\
\text { digunakan sesuai dengan } \\
\text { kebutuhan posyandu? }\end{array}$ & 0 & 10 & 0 & 0 & 0 \\
\hline 7 & $\begin{array}{l}\text { Apakah desain tampilan } \\
\text { sudah memudahkan } \\
\text { pengguna? }\end{array}$ & 0 & 6 & 4 & 0 & 0 \\
\hline \multicolumn{7}{|c|}{ Keterangan bobot nilai. } \\
\hline \multicolumn{2}{|c|}{ Sangat Baik (SB) } & & & & & \\
\hline \multicolumn{2}{|c|}{ Baik (B) } & & & & & \\
\hline \multicolumn{2}{|c|}{ Cukup Baik (CB) } & & & & & \\
\hline \multicolumn{2}{|c|}{ Tidak Baik (TB) } & & & & & \\
\hline \multicolumn{7}{|c|}{ Sangat Tidak Baik (STB) : 1} \\
\hline
\end{tabular}

Tabel 2. Prosentase Skor Interval

\begin{tabular}{|c|c|c|}
\hline No. & Keterangan & Persentase Penilaian \\
\hline 1 & Sangat Tidak Baik & $0 \%-20 \%$ \\
\hline 2 & Tidak Baik & $21 \%-40 \%$ \\
\hline 3 & Cukup Baik & $41 \%-60 \%$ \\
\hline 4 & Baik & $61 \%-80 \%$ \\
\hline 5 & Sangat Baik & $81 \%-100 \%$ \\
\hline
\end{tabular}

Dari pengujian yang dilakukan dapat disimpulkan bahwa persentase tertinggi didapat oleh pertanyaan $1,3,4,5,6$ dengan perolehan sama yaitu $80 \%$ (Baik), dan terendah yaitu ke 7 mendapat 72\% (Baik), dari 10 penguji menyatakan aplikasi Baik untuk digunakan

\section{KESIMPULAN}

Merujuk pada semua pembahasan yang telah dilakukan mengenai aplikasi monitoring perkembangan anak pada Posyandu Gunggungan Lor dapat disimpulkan yaitu, telah dihasilkan aplikasi monitoring anak pada Posyandu Gunggungan lor berbasis android, dimana aplikasi tersebut dapat memudahkan ibu balita dalam memonitoring perkembangan anak, hal ini berdasarkan hasil jawaban responden pada pengujian eksternal, yang telah dilakukan pengujian kepada 10 responden dengan memilih skor Baik dan Cukup Baik, dari hasil perhitungan jumlah pada pertanyaan 1 menghasilkan $80 \%$ baik, $72 \%$ baik pada pertanyaan 2, 80\% baik pada pertanyaan 3, $80 \%$ baik pada pertanyaan $4,80 \%$ baik pada pertanyaan $5,80 \%$ baik pada pertanyaan 6 , dan $48 \%$ baik pada pertanyaan 7. Maka berdasarkan hasil tersebut disimpulkan bahwa aplikasi ini dapat berjalan dengan baik dan dapat digunakan pada posyandu Gunggungan Lor.

\section{DAFTAR PUSTAKA}

Enterprise, J. (2018). HTML, PHP, dan MySQL untuk Pemula. Jakarta: Elex Media Komputindo.

Fitriana, S. (2019). Perancangan Sistem Tumbuh Kembang Balita dengan Metode Forward Chaining. IJSE - Indonesian Journal on Software Engineering , 5 (2), 149-159.

Hendriyani, Y., \& Suryani, K. (2020). Pemrograman Android Teori dan Aplikasi. Pasuruan: CV. Penerbit Qiara Media.

Humas. (2015, Juli 24). Pengertian Monitoring dan Evaluasi Kebijakan Pemerintah. Retrieved Maret 11, 2021, from Sekretariat Kabinet Republik Indonesia: https://setkab.go.id/pengertianmonitoring-dan-evaluasi-kebijakanpemerintah/

Khaironi, M. (2018). Perkembangan Anak Usia Dini. Jurnal Golden Age Hamzanwadi University , 3 (1), 1-12.

Oetomo, H. W., \& Mahargiono, P. B. (2020). ECommerce: Aplikasi PHP dan MySQL pada Bidang Manajemen. Yogyakarta: Penerbit Andi.

Perwitasari, I. D., \& Hendrawan, J. (2020). Rancang Bangun Sistem E-Posyandu Penjadwalan dan Monitoring Perkembangan Bayi Berbasis Android. Journal of Information Technology and Computer Science (INTECOMS) , 3 (1), 1-8.

Rachmadi, T. (2020). Sistem Basis Data. Jakarta: Tiga Ebook.

Rusmawan, U. (2019). Tenik Penulisan Tugas Akhir dan Skripsi Pemrograman. Jakarta: Elex Media Komputindo. 
Sanitasari, R. D., Andreswari, D., \& Purwandari, E. P. (2017). Sistem Monitoring Tumbuh Kembang Anak Usia 0-5 Tahun Berbasis Android. Juranl Rekursif , 5 (1), 1-10.

Setyawati, V. A., \& Hartini, E. (2018). Buku Ajar Dasar Ilmu Gizi Kesehatan Masyarakat. Sleman: Deepublish.

Sitorus, L. (2015). Algoritma dan Pemrograman. Yogyakarta: Andi Offset.

Solichin, A. (2016). Pemrograman Web dengan PHP dan MySQL. Jakarta: Penerbit Budi Luhur.

Sulistyowati, L. S., \& Gempari, R. (2011). Pedoman Umum Pengelolaan Posyandu. Jakarta: Kementrian Kesehatan RI.

Suprapto, U. (2021). Pemodelan Perangkat Lunak SMK/MAK Kelas IX. Jakarta: Gramedia Widiasarana Indonesia .

Suryadi, S. (2019). Implementasi Normalisasi Dalam Perancangan Database Relational. U-NET : Jurnal Teknik Informatika , 3 (2), 1-5.
Triana, L., Andryani, R., \& Kurniawan. (2021). Aplikasi Monitoring Data Imunisasi Berkala untuk Meningkatkan Pelayanan Posyandu Menggunakan Metode RAD Berbasis Android. Jurnal SISFOKOM (Sistem Informasi dan Komputer) , 10 (1), 106-112.

Utami, F. H., \& Asnawati. (2015). Rekayasa Perangkat Lunak. Yogyakarta: Deepublish.

Weli. (2019). Aplikasi Kasus Siklus Transaksi Bisins. Jakarta: Penerbit Unika Atma Jaya.

Widyawati. (2018, September 24). Ayo Tingkatkan Pemanfaatan Buku KIA untuk Pantau Kesehatan Ibu dan Anak. Retrieved Maret 12, 2021, from Sehat Negeriku: https://sehatnegeriku.kemkes.go.id/baca/umu m/20180919/0627969/ayo-tingkatkanpemanfaatan-buku-kia-pantau-kesehatan-ibudan-anak/

Yuniansyah. (2020). Algoritma dan Pemrograman Menggunakan Bahasa Pemrograman Java (Teori dan aplikasinya). Bogor: Penerbit Lindan Bestari. 